\title{
Turbulence mapping: a new CMR approach for assessment of aortic stenosis
}

\author{
Petter Dyverfeldt ${ }^{1,2^{*}}$, Michael D Hope ${ }^{1}$, Elaine E Tseng ${ }^{1}$, David Saloner ${ }^{1}$ \\ From 16th Annual SCMR Scientific Sessions \\ San Francisco, CA, USA. 31 January - 3 February 2013
}

\section{Background}

Pressure loss estimation based on the simplified Bernoulli equation frequently misclassifies the severity of aortic stenosis. Consequently, several investigators have on the basis of fluid dynamics theory derived pressure loss indices aimed at improving the clinical approach to pressure estimation [1-3]. However, CMR may offer a stronger alternative. The primary cause of pressure loss in aortic stenosis is dissipation of turbulent kinetic energy (TKE) into heat. New CMR methods permit direct estimation TKE [4]. We sought to evaluate the relationship between CMR-measured TKE and previously described pressure loss indices.

\section{Methods}

27 patients under evaluation for aortic valve replacement were enrolled. The patient population represents a broad range of aortic stenosis and aortic dilation. Aortic valve area was $1.6 \pm 1.7 \mathrm{~cm}^{2}$ (mean \pm std dev), range: $0.4-6.4 \mathrm{~cm}^{2}$. Peak velocity was $3.7 \pm 1.4 \mathrm{~m} / \mathrm{s}$, range 2.0 $-7.5 \mathrm{~m} / \mathrm{s}$. Maximum aortic diameter was $4.1 \pm 0.8 \mathrm{~cm}$, range $3.0-6.1 \mathrm{~cm}$.

TKE was estimated using a novel 4D Flow CMR method, as described in [4]. A measure of the total TKE $\left(\mathrm{TKE}_{\text {tot }}\right)$ was obtained by integrating the TKE per voxel across the ascending aorta. Each subject had clinical echocardiography and computed tomography studies done close to the CMR study.

$\mathrm{TKE}_{\text {tot }}$ was compared against three pressure loss indices (iPL) derived from the literature [1-3] (see table in figure 1). These indices represent different approaches to estimate pressure loss effects based on data obtainable with noninvasive imaging. The underlying theory has been compared favorably with catheter-based measurements in select settings [1-3].

${ }^{1}$ University of California San Francisco, San Francisco, CA, USA

Full list of author information is available at the end of the article

\section{Results}

Scatter plots for $\mathrm{TKE}_{\text {tot }} \mathrm{Vs} \mathrm{iPL}_{1}, \mathrm{iPL}_{2}$, and $\mathrm{PL}_{3}$ are shown in Figure 2. Correlation for $\mathrm{TKE}_{\text {tot }} \mathrm{vs}_{\mathrm{PPL}}, \mathrm{TKE}_{\text {tot }} \mathrm{vs} \mathrm{iPL}_{2}$, and $\mathrm{TKE}_{\text {tot }} \mathrm{vs}_{\mathrm{PL}}$ was $0.65,0.87,0.92$, respectively. The slope was significantly different from zero in all cases.

\section{Conclusions}

This study used a novel CMR flow imaging method to measure the total TKE in the ascending aorta of patients with aortic stenosis. Strong correlation was found between TKE and pressure loss indices derived from fluid dynamics theory. By directly measuring the source of irreversible pressure loss, TKE mapping allows new avenues for evaluation of aortic stenosis with CMR. Future work will include a comparison between CMR-measured TKE and catheter-based pressure measurements.

\section{Funding}

Fulbright Commission

Swedish Heart-Lung Foundation

Swedish Brain Foundation.

\begin{tabular}{|ccc|}
\hline Expression & $\begin{array}{c}\text { Theoretical relation to } \\
\text { pressure gradients }\end{array}$ & $\begin{array}{c}\text { Described in } \\
\text { references }\end{array}$ \\
\hline $\mathrm{iPL}_{1}=\left(\mathrm{Q} \frac{\mathrm{A}_{\mathrm{A}}-\mathrm{AVA}}{\mathrm{AVAx} \mathrm{A}_{\mathrm{A}}}\right)^{2}$ & $\mathrm{iPL}_{1}=\mathrm{TPG}_{\text {net }}$ & {$[1,2]$} \\
$\mathrm{PPL}_{2}=\mathrm{Q}\left(1-\frac{\mathrm{AVA}}{\mathrm{A}_{\mathrm{A}}}\right)^{2}$ & $\mathrm{iPL}_{2}=\mathrm{Q} \frac{\mathrm{TPG}_{\text {net }}}{\mathrm{TPG}_{\max }}$ & {$[1,2]$} \\
$\mathrm{PPL}_{3}=2 \mathrm{Q}\left(\frac{\mathrm{AVA}}{\mathrm{A}_{\mathrm{A}}}-\left(\frac{\mathrm{AVA}}{\mathrm{A}_{\mathrm{A}}}\right)^{2}\right)$ & $\mathrm{iPL}_{3}=\mathrm{Q} \frac{\mathrm{TPG}_{\text {net }}}{\mathrm{TPG}_{\max }}$ & {$[3]$} \\
\hline
\end{tabular}

Figure 1 Table of pressure loss indices (iPL) used in this study, along with references from which they were derived. ${ }^{*}{ }^{T P G_{m a x}}$ and $T P G_{\text {net }}$ denote maximum and net transvalvular pressure gradient, respectively. $Q=$ peak systolic flow rate, $A V A=$ aortic valve area, $A_{A}$ = aortic area at sinotubular junction. $Q, A V A$ and $A_{A}$ were obtained from MRI, echocardiography and computed tomography, respectively. 

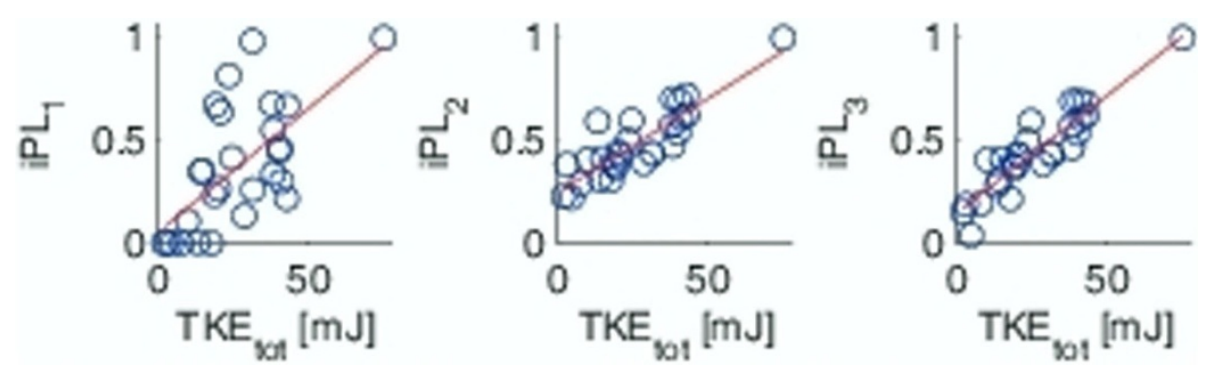

Figure 2 Total turbulent kinetic energy ( $T K E_{\text {tot }}$ ) in the ascending aorta plotted against the pressure loss indices (iPL) described in Table 1. All indices were normalized to have a maximum value of $\mathrm{PPL}=1$. TKE ascending aorta. Solid line: estimated regression line.

\section{Author details}

${ }^{1}$ University of California San Francisco, San Francisco, CA, USA. ${ }^{2}$ Linköping

University, Linköping, Sweden.

Published: 30 January 2013

\section{References}

1. Garcia D, et al.. Circ 2000

2. Garcia D, et al:. JACC 2003.

3. Voelker W, et al:. JACC 1992.

4. Dyverfeldt $P$, et al:. JMRI 2008.

doi:10.1186/1532-429X-15-S1-P110

Cite this article as: Dyverfeldt et al:: Turbulence mapping: a new CMR approach for assessment of aortic stenosis. Journal of Cardiovascular Magnetic Resonance 2013 15(Suppl 1):P110.

Submit your next manuscript to BioMed Central and take full advantage of:

- Convenient online submission

- Thorough peer review

- No space constraints or color figure charges

- Immediate publication on acceptance

- Inclusion in PubMed, CAS, Scopus and Google Scholar

- Research which is freely available for redistribution

Submit your manuscript at www.biomedcentral.com/submit 